\title{
IRON AND COPPER COMPLEXATION IN THE MACARONESIAN COASTAL WATERS
}

\author{
VERONICA ARNONE, MELCHOR GONZÁLEZ-DÁVILA, \\ ARIDANE G. GONZÁLEZ AND PROF. J. MAGDALENA \\ SANTANA-CASIANO \\ Universidad de Las Palmas de Gran Canaria (ULPGC) \\ Presenting Author: veronica.arnone101@alu.ulpgc.es
}

The coastal waters around the oceanic islands represent dynamic environments affected by complex interactions between the topography and the general circulation of water and winds. Different sources and mixing processes influence the distribution of dissolved iron $(\mathrm{dFe})$ and copper $(\mathrm{dCu})$ concentration, as well as those of their organic binding ligands $\left(\mathrm{L}_{\mathrm{Fe}}\right.$ and $\left.\mathrm{L}_{\mathrm{Cu}}\right)$. In this work, the speciation of $\mathrm{dFe}$ and $\mathrm{dCu}$ was investigated in the surface coastal waters of three archipelagos along the Macaronesia region (Cape Verde, Canary Islands and Madeira). During the POS533 cruise (February-March 2019), also two oceanic stations were sampled located at the Cape Verde Ocean Observatory (CVOO) station and at the European Station for Time Series in the Ocean at the Canary Islands (ESTOC). Metal and ligand concentration, and the conditional stability constants were measured by the competitive ligand exchange-adsorptive cathodic stripping voltammetry (CLE-ACSV). Along the region, $\mathrm{L}_{\mathrm{Fe}}$ levels $(0.56-2.96 \mathrm{nM})$ were always higher than the $\mathrm{dFe}$ concentration (0.46-1.32 nM), where more than $98 \%$ of dFe was organically complexed. The conditional stability constant (log K ${ }_{\mathrm{Fe} 3+\mathrm{L}}$ ) presented values between 20.77 and 21.90. On the other hand, $\mathrm{dCu}$ was between 0.07 and $4.03 \mathrm{nM}$ while $\mathrm{L}_{\mathrm{Cu}}$ concentration was in the range of $0.54-2.59 \mathrm{nM}$. In this case, more than $99 \%$ of $\mathrm{dCu}$ was complexed. The conditional stability constant $\left(\log \mathrm{K}_{\mathrm{Cu} 2+\mathrm{L}}^{\prime}\right)$ showed values between 13.40 and 14.42. Dissolved metal and ligand concentrations for $\mathrm{Fe}$ and $\mathrm{Cu}$ presented different distribution of maximum and minimum values. However, in many stations $\mathrm{L}_{\mathrm{Fe}}$ and $\mathrm{L}_{\mathrm{Cu}}$ values overlapped suggesting a common source of ligand or that at least some of these are not specific to a single metal. The amount of dissolved metals and ligands from coastal stations are greater than those from ocean sites indicating that the processes that take place around the islands influence the metal speciation. In addition, it has been observed that on the east coasts the increase in concentrations could be related with a greater incidence of wind and dynamic process that mobilize sediments and favour the waters mixing. These results will increase our knowledge about the impact of coastal areas on the $\mathrm{Fe}$ and $\mathrm{Cu}$ biogeochemical cycles. 